\title{
ANALISIS KUALITAS LAYANAN BONGKAR MUAT DI PT TERMINAL PETIKEMAS SURABAYA DENGAN METODE SERVQUAL DAN QFD
}

\author{
Endhy Bastian $^{1)}$, Vita Ratnasari ${ }^{2}$, dan Fuad Achmadi ${ }^{3)}$ \\ 1)Program Studi Magister Manajemen Teknologi, Institut Teknologi Sepuluh Nopember \\ 2) Jurusan Statistika, Institut Teknologi Sepuluh Nopember \\ 3)Program Studi Magister Manajemen Teknologi, Institut Teknologi Sepuluh Nopember \\ e-mail: endhybastian@gmail.com
}

\begin{abstract}
PT Terminal Petikemas Surabaya (TPS) has become one of the port services company has been trusted by various Indonesian and international companies in the management of international and domestic containers as well as various other loading and unloading services. PT TPS in providing international container management services is required to adjust its service level in accordance with international standards. Based on the Key Performance Indicator (KPI), the performance of PT TPS compared to some international ports in terms of Trund-Around Time (TRT), Gross Mover Per Hour (GMPH), and Berth Move Per Hour (BMPH) are still far behind with ports in UAE, Asia Pacific and India. The low performance of PT TPS based on the three indicators shows that the quality of service PT TPS still needs to be repaired.

In this research, perception analysis and customer expectation with Service Quality (SERVQUAL) method to measure service quality of PT TPS. The gap between perception and customer expectation from Service Quality (SERVQUAL) is improved by Quality Function Deployment (QFD) method. And based on the two analysis, the preparation of strategies that should be applied by PT TPS to improve the quality of service.

The results obtained show that all dimensions have satisfaction level "satisfied" which means that customers value the services provided by PT TPS is enough to meet expectations but still not maximal. Furthermore, Cartesius diagram analysis showed that there are 5 indicators that need improvement either immediately. The QFD analysis is performed to determine the recommended improvements on 5 indicators. Indicators that require top priority are indicators related to the competence of officers, especially administrative officers. So the management recommendation is to make Standard Operating Procedure (SOP) for each activity in port for administration officer.
\end{abstract}

Keywords: Customer Satisfaction, Gap Analysis, Quality Function Deployment

\section{PENDAHULUAN}

Keberadaan terminal petikemas memiliki peran yang strategis dalam suatu sistem rantai pasok dan logistik untuk meningkatkan kinerja arus barang dari dan ke suatu wilayah. Peran utama dari terminal petikemas adalah sebagai sarana transportasi barang dari tempat asal pengiriman menuju tempat tujuan. Peran terminal petikemas sebagai sarana transportasi barang ini meliputi pelayanan dalam penyediaan akses transportasi bongkar muat petikemas dari kapal ke darat maupun sebaliknya dan juga sebagai tempat pelayanan dalam penumpukan petikemas. PT Terminal Petikemas Surabaya (PT TPS) merupakan anak perusahaan dari PT Pelabuhan Indonesia III (Persero), sebagai operator pelabuhan selama satu dekade, PT TPS telah banyak dipercaya oleh berbagai perusahaan Indonesia maupun mancanegara dalam pengelolaan petikemas internasional dan terminal petikemas domestik maupun berbagai jasa bongkar muat penunjang lainnya. PT TPS dalam memberikan pelayanan pengelolaan petikemas internasional sudah 
menjadi keharusan untuk menyesuaikan tingkat pelayanannya sesuai dengan standar internasional. Berdasarkan data capaian dari PT TPS yang ditunjukkan dari Key Performance Indicator (KPI), pencapaian Trund-Around Time (TRT) PT TPS tidak berbeda jauh dengan beberapa pelabuhan di negara Uni Emirat Arab (UEA), di mana nilai TRT sebesar 28 menit. Sementara berdasarkan nilai GMPH, pencapaian PT TPS sebesar $26 \mathrm{MPH}$, tertinggal dari seluruh pelabuhan internasional lainnya, terutama UEA yang sebesar $34 \mathrm{MPH}$, dan BMPH PT TPS sebesar $46 \mathrm{MPH}$ jauh tertinggal dengan pelabuhan UEA yang sebesar $145 \mathrm{MPH}$. Berdasarkan kondisi tersebut terlihat bahwa kecepatan proses bongkar muat dalam hal ini produktivitas QC GMPH dan Produktivitas VSL BMPH masih jauh bila dibandingkan dengan berbagai pihak. Kondisi tersebut menjadi penilaian tersendiri bagi pengguna jasa pelabuhan, di mana semakin lama proses bongkar muat maka pengguna jasa pelabuhan harus menyediakan ekstra biaya beban operasional. Selain itu, kondisi tersebut juga menunjukkan bahwa kualitas pelayanan PT TPS masih perlu untuk dilakukan perbaikan.

Berdasarkan hal tersebut peningkatan kepuasan pengguna jasa terhadap layanan PT TPS dari semua sisi baik fasilitas dan sarana, SDM serta operasional sangat diperlukan untuk membuat kepercayaan pelanggan terjaga dan berdampak pada semakin besarnya kemajuan PT TPS. Berdasarkan pemaparan di atas, maka dilakukan penelitian ini untuk menganalisis persepsi dan harapan pelanggan dengan metode service quality (servqual) untuk mengukur kualitas layanan PT Terminal Petikemas Surabaya. Metode servqual ini digunakan untuk mengklasifikasikan layanan perusahaan berdasarkan lima dimensi kualitas layanan (bukti langsung/tangibles, kean- dalan/reliability, daya tanggap/responsiveness, jaminan/assurance, dan empati/empathy). Hasil pengukuran kesenjangan (gap) antara persepsi dan harapan pelanggan dievaluasi dengan metode Quality Function Deployment (QFD). Selanjutnya berdasarkan pengukuran kesenjangan (gap) dan QFD, dilakukan penyusunan strategi-strategi yang sebaiknya dilakukan oleh PT Terminal Petikemas Surabaya untuk meningkatkan kualitas pelayanan.

\section{METODE}

Secara garis besar penelitian ini terdiri atas dua tahap, tahap awal dan tahap analisis data. Tahap awal merupakan tahapan pembuatan kuesioner dan pengumpulan data. Sedangkan tahap analisis data meliputi analisis gap, analisis diagram kartesius, dan QFD.

\section{Tahap Pembuatan Kuesioner dan Pengumpulan Data}

Pada tahapan pembuatan kuesioner, ditentukan indikator-indikator dari kelima dimensi service quality (servqual) dalam pelayanan jasa terminal petikemas. Indikator-indikator tersebut merujuk pada penelitian Randheer, Al-Motawa (2011).

Indikator-indikator dari masing-masing variabel disusun untuk membandingkan Perceived Service (realita) dengan Expectation (harapan) yang didasarkan pada Level of Importance, dengan skala pengukuran (1) sangat tidak puas, (2) tidak puas, (3) cukup, (4) puas, (5) sangat puas. Selanjutnya dilakukan pengumpulan data dengan metode survei kepada 60 pelanggan petikemas domestik PT TPS. 
Tabel 1 Indikator-Indikator Kepuasan Pelanggan Terminal Petikemas

\begin{tabular}{|c|c|}
\hline $\begin{array}{c}\text { Dimensi Kualitas } \\
\text { Pelayanan } \\
\text { (Kotler \& Keller, 2014) } \\
\end{array}$ & Indikator Kualitas Pelayanan yang digunakan (Al-Motowa, 2011) \\
\hline \multirow{9}{*}{$\begin{array}{l}\text { Penampilan Fisik } \\
\quad(\text { Tangible })\end{array}$} & A1: Kelayakan kondisi dermaga kapal \\
\hline & A2: Lapangan penumpukan kontainer memadai dan layak \\
\hline & A3: Lapangan penumpukan kontainer tertata rapi \\
\hline & A4: Penampilan petugas di lapangan baik dan komunikatif \\
\hline & $\begin{array}{l}\text { A5: Tercukupinya jumlah petugas (administrasi, operasional tally, } \\
\text { dan TKBM) }\end{array}$ \\
\hline & $\begin{array}{l}\text { A6: Kondisi alat bongkar muat di terminal (forklift, RS, RTG, } \\
\text { HMC) baik dan terawat }\end{array}$ \\
\hline & $\begin{array}{l}\text { A7: Jumlah alat bongkar muat di terminal (forklift, RS, RTG, } \\
\text { HMC) memadai }\end{array}$ \\
\hline & A8: Papan informasi tersedia dengan baik dan memadai \\
\hline & A9: Fasilitas umum dalam kondisi baik dan memadai \\
\hline \multirow{9}{*}{$\begin{array}{l}\text { Keandalan } \\
\text { (Reliability) }\end{array}$} & B10: Kesesuaian jadwal sandar kapal ke dermaga \\
\hline & B11: Kesesuaian jadwal bongkar muat kapal \\
\hline & $\begin{array}{l}\text { B12: Pelayanan petugas operasional tally dermaga dan lapangan } \\
\text { cepat dan tepat }\end{array}$ \\
\hline & $\begin{array}{l}\text { B13: Petugas administrasi memberikan pelayanan dengan cepat } \\
\text { dan tepat }\end{array}$ \\
\hline & $\begin{array}{l}\text { B14: Petugas TKBM memadai dan terampil dalam memberikan } \\
\text { pelayanan }\end{array}$ \\
\hline & B15: Alat bongkar muat memiliki produktivitas yang tinggi \\
\hline & $\begin{array}{l}\text { B16: Tarif yang ditentukan sesuai dengan layanan jasa yang } \\
\text { diberikan }\end{array}$ \\
\hline & B17: Kemudahan dalam sistem pembayaran \\
\hline & B18: Aktivitas bongkar muat tercatat dengan baik dan benar \\
\hline \multirow{5}{*}{$\begin{array}{l}\text { Tanggapan } \\
\text { (Responsiveness) }\end{array}$} & $\begin{array}{l}\text { C19: Petugas administrasi memberikan informasi jelas dan mudah } \\
\text { dimengerti }\end{array}$ \\
\hline & $\begin{array}{l}\text { C20: Petugas admin mampu memberikan solusi yang baik dan } \\
\text { tepat terhadap permasalahan administrasi }\end{array}$ \\
\hline & $\begin{array}{l}\text { C21: Petugas operasional tally dermaga dan lapangan menerima } \\
\text { dan menanggapi keluhan pelanggan dengan cepat }\end{array}$ \\
\hline & $\begin{array}{l}\text { C22: Problem terhadap alat bongkar dapat terselesaikan dengan } \\
\text { cepat dan tepat oleh petugas }\end{array}$ \\
\hline & C23: Sarana informasi di area terminal dapat diakses 24 jam \\
\hline \multirow{6}{*}{$\begin{array}{l}\text { Kepastian } \\
\text { (Assurance) }\end{array}$} & $\begin{array}{l}\text { D24: Petugas operasional post security tanggap terhadap } \\
\text { keamanan dan ketertiban }\end{array}$ \\
\hline & $\begin{array}{l}\text { D25: Penerapan operasional di lapangan sesuai dengan Sistem } \\
\text { Operasional Prosedur (SOP) }\end{array}$ \\
\hline & D26: Peraturan-peraturan dijalankan dengan baik dan benar \\
\hline & $\begin{array}{l}\text { D27: Terdapat sangsi tegas jika ada penyimpangan terhadap } \\
\text { peraturan dan SOP }\end{array}$ \\
\hline & $\begin{array}{l}\text { D28: Petugas operasional tally dermaga dan lapangan memiliki } \\
\text { kompetensi }\end{array}$ \\
\hline & D29: Petugas administrasi memiliki kompetensi \\
\hline \multirow{3}{*}{$\begin{array}{l}\text { Empati } \\
\text { (Emphaty) }\end{array}$} & $\begin{array}{l}\text { E30: Petugas administrasi terminal melayani dengan ramah dan } \\
\text { sopan }\end{array}$ \\
\hline & $\begin{array}{l}\text { E31: Petugas operasional tally dermaga dan lapangan melayani } \\
\text { dengan ramah dan sopan }\end{array}$ \\
\hline & E32: Petugas bertanggung jawab terhadap kenyamanan pelanggan \\
\hline
\end{tabular}




\section{Tahap Analisis Gap}

Pada tahap ini dilakukan pengukuran tingkat kepuasan pelanggan menggunakan rentang Gap di mana definisi dari tingkat kepuasan menurut Kotler (1997) adalah fungsi dari perbedaan antara kinerja yang dirasakan dengan harapan. Sehingga pengukuran kepuasan dilakukan dengan membandingkan nilai-nilai variabel yang memengaruhi tingkat persepsi kenyataan yang dirasakan pelanggan terhadap suatu kualitas pelayanan dibandingkan dengan harapan pelanggan. Adapun rentang Gap tingkat kepuasan kualitas layanan dapat ditentukan dan dikaitkan dengan Customer Satisfaction Index (CSI) sebagai berikut. Rentang GAP = Nilai Kenyataan (K) - Nilai Harapan (H) (1)

Klasifikasi tingkat kepuasan yang diukur dengan menggunakan analisis Gap dapat dilihat pada tabel berikut (Aritonang, 2005).

\begin{tabular}{|c|c|c|}
\hline Gap & Tingkat Kepuasan & CSI \\
\hline$>0,00$ & Sangat Puas (SP) & $>100$ \\
\hline$-0,15 \leq$ Gap $\leq 0,00$ & Puas (P) & $85-100$ \\
\hline$-0,30 \leq$ Gap $<-0,15$ & Cukup Puas (CP) & $70-<85$ \\
\hline$-0,45 \leq$ Gap $<-0,30$ & Kurang Puas (KP) & $55-<70$ \\
\hline Gap $<-0,45$ & Tidak Puas (TP) & $<55$ \\
\hline
\end{tabular}

Apabila nilai rentang Gap positif berarti konsumen merasa pelayanan yang diterima telah sesuai dengan yang diharapkan. Namun bila rentang Gap negatif maka konsumen merasa kualitas pelayanan yang diberikan belum sesuai dengan harapan.

\section{Tahap Analisis Diagram Kartesius}

Diagram kartesius dapat digunakan untuk menentukan prioritas dari faktor-faktor kepuasan. Pada diagram kartesius sumbu mendatar (X) diisi oleh rentang rata-rata skor penilaian pelayanan, sementara sumbu tegak $(\mathrm{Y})$ diisi oleh rentang rata-rata skor penilaian harapan pelanggan. Pada kedua sumbu ini terdapat batas yang berupa rata-rata total dari skor penilaian pelayanan dan skor penilaian harapan pelanggan untuk membentuk empat kuadran prioritas. Kedua ratarata total tersebut dirumuskan sebagai berikut.

$\overline{\bar{X}}=\frac{\sum_{i=1}^{N} X_{i} / N}{K}$ dan $\overline{\bar{Y}}=\frac{\sum_{i=1}^{N} Y_{i} / N}{K}$

di mana

$\mathrm{N}=$ jumlah responden

$\mathrm{K}=$ jumlah faktor kepuasan pelanggan

Tingkat kesesuaian untuk masing-masing faktor kepuasan pelanggan selanjutnya digambarkan ke dalam empat kuadran pada diagram kartesius seperti yang ditunjukkan pada gambar berikut.

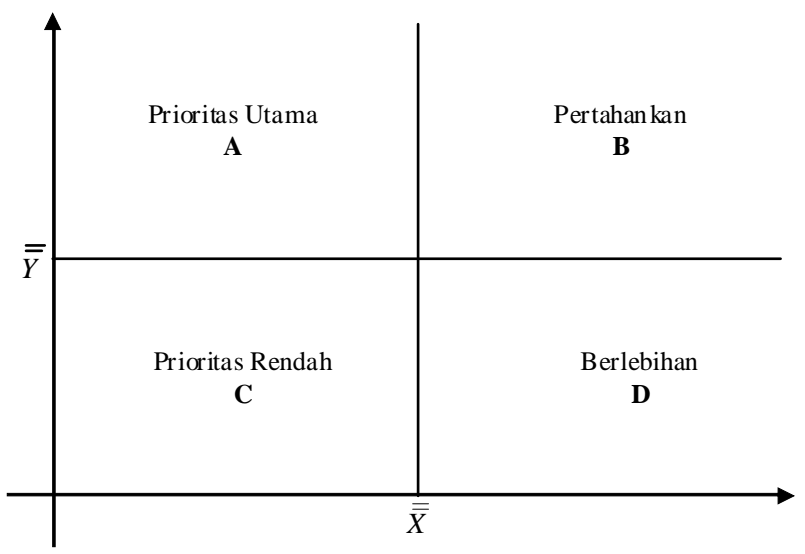

Gambar 1 Diagram Kartesius

Maksud dari masing-masing kuadran pada diagram kartesius tersebut dijelaskan sebagai berikut (Supranto, 2001).

1. Kuadran A

Atribut yang dianggap sangat penting untuk responden, tetapi tingkat kinerja yang cukup rendah. Ini mengirimkan pesan langsung yang menunjukkan bahwa upaya perbaikan harus berkonsentrasi di sini.

2. Kuadran B

Atribut yang dianggap sangat penting untuk responden, dan pada saat yang sama, manaje- 
men tampaknya memiliki tingkat kinerja yang tinggi pada kegiatan ini. Sehingga manajemen harus mempertahankan baiknya kinerja atribut yang berada pada kuadran ini.

3. Kuadran $\mathrm{C}$

Atribut dianggap memiliki kepentingan rendah dan kinerja rendah. Meskipun tingkat kinerja mungkin rendah dalam sel ini, manajemen tidak perlu terlalu khawatir karena atribut dalam sel ini tidak dianggap sangat penting.

4. Kuadran D

Sel ini berisi atribut dengan kepentingan rendah, tetapi relatif tinggi kinerja sehingga atribut pada sel ini dimungkinkan untuk ditiadakan dan diganti dengan aspek kepuasan lainnya.

\section{Tahap Quality Function Deployment (QFD)}

1. Mengidentifikasikan kemauan pelanggan. Dalam hal ini, pelanggan atau konsumen ditanya mengenai sifat yang diinginkan dari suatu produk.

2. Mempelajari ketentuan teknis dalam menghasilkan barang atau jasa. Hal ini didasarkan data yang tersedia. Aktivitas dan sarana yang digunakan dalam menghasilkan barang atau jasa, dalam rangka menentukan mutu pemenuhan kebutuhan pelanggan.

3. Hubungan antara keinginan pelanggan dengan ketentuan teknis. Hubungan ini dapat berpengaruh kuat, sedang atau lemah. Setiap aspek dari konsumen diberi bobot, untuk membedakan pengaruhnya terhadap mutu produk.

\section{HASIL DAN PEMBAHASAN}

Pembahasan penelitian yang terdiri dari pengukuran besarnya kesenjangan antara persepsi dengan harapan yang dirasakan pelanggan terhadap layanan PT TPS dan rekomendasi perbaikan untuk perencanaan dan pengembangan pelayanan. Pengukuran kesenjangan persepsi dan harapan dianalisis menggunakan analisis Gap dan diagram kartesius, sementara rekomendasi perbaikan layanan dianalisis dengan metode Quality Function Deployment (QFD) dijabarkan sebagai berikut.

\section{Analisis Gap}

Berdasarkan nilai-nilai kesenjangan pada hasil yang diperoleh menunjukkan nilai gap negatif untuk semua dimensi kepuasan mulai dari penampilan fisik (tangible), keandalan (reliability), tanggapan (responsiveness), kepastian (assurance), dan empati (empathy) sehingga memiliki arti bahwa nilai kualitas untuk dimensidimensi tersebut masih belum memenuhi ekspektasi pelanggan. Jika nilai kesenjangan (gap) tersebut dikelompokkan berdasarkan tingkat kepuasan CSIndex menghasilkan tingkat kepuasan "cukup puas" untuk setiap dimensi. Hasil tersebut sama dengan akumulasi penilaian tingkat kepuasan secara keseluruhan. Hal ini dapat diartikan bahwa pada seluruh pelanggan petikemas menilai pelayanan yang diberikan PT TPS sudah cukup memenuhi harapan secara keseluruhan maupun pada masing-masing dimensi namun masih belum maksimal. Tabel 2 juga memperlihatkan bahwa dimensi ketanggapan memiliki nilai gap terbesar yaitu $(1,133)$ dibandingkan dimensi-dimensi kepuasan pelanggan lainnya sehingga dimensi ini perlu mendapatkan evaluasi dari pihak perusahaan.

Tabel 2 Akumulasi Penilaian Kepuasan Pelanggan PT BJTI

\begin{tabular}{|l|c|c|c|c|}
\hline \multicolumn{1}{|c|}{ Dimensi } & Harapan & Realita & Gap & $\begin{array}{c}\text { Tingkat } \\
\text { Kepuasan }\end{array}$ \\
\hline Penampilan Fisik (Tangible) & 4,519 & 3,642 & $-0,878$ & Cukup Puas \\
\hline Keandalan (Reliability) & 4,657 & 3,811 & $-0,846$ & Cukup Puas \\
\hline Ketanggapan (Responsiveness) & 4,558 & 3,425 & $-1,133$ & Cukup Puas \\
\hline Kepastian (Assurance) & 4,590 & 3,703 & $-0,887$ & Cukup Puas \\
\hline Empati (Empathy) & 4,578 & 3,622 & $-0,956$ & Cukup Puas \\
\hline Rata-rata & 4,581 & 3,641 & $-0,940$ & Cukup Puas \\
\hline
\end{tabular}




\section{Analisis Diagram Kartesius}

Hasil analisis menggunakan Importance Perfomance Analysis (IPA) yang berupa diagram kartesius PT TPS ditunjukkan pada Gambar 2 berikut.

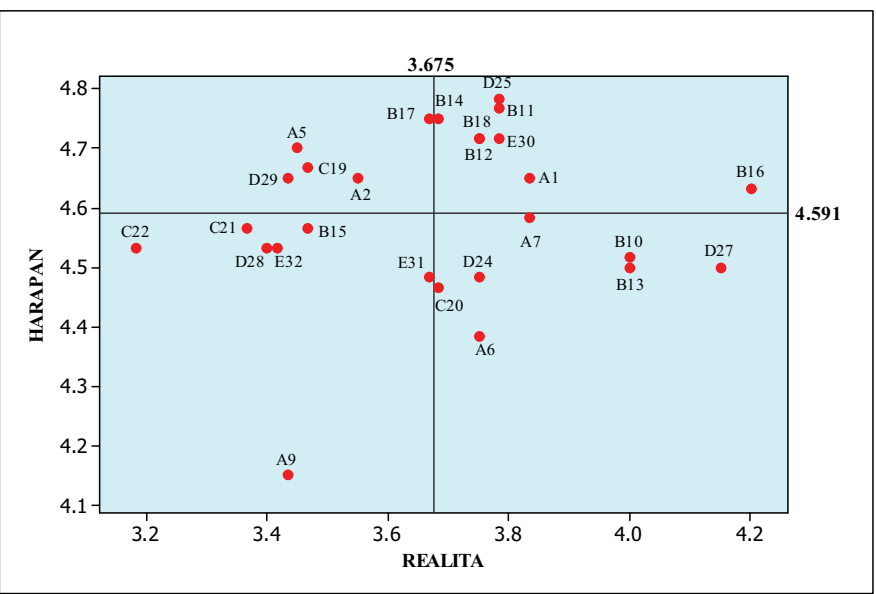

Gambar 2 Diagram Kartesius Kepuasan Pelanggan Petikemas Domestik PT TPS
Gambar 2 empat kuadran kepuasan pelanggan hasil analisis diagram kartesius. Pada gambar tersebut 5 indikator masuk ke dalam Kuadran I yang berarti aspek layanan tersebut harus diperbaiki segera, 8 indikator masuk ke dalam Kuadran II yang berarti aspek layanan tersebut harus dipertahankan, 7 indikator masuk ke dalam Kuadran III yang berarti aspek layanan tersebut perbaikannya dapat ditunda, dan 7 indikator masuk ke dalam Kuadran IV yang berarti aspek layanan tersebut dimungkinkan untuk ditiadakan dan diganti dengan aspek kepuasan lainnya.

Hasil dari diagram kartesius menunjukkan pengelompokan indikator-indikator dalam empat kuadran prioritas perbaikan yaitu Kuadran I di mana indikator yang dianggap penting tetapi kualitas layanannya cukup rendah.

Tabel 3 Pengelompokan Indikator Berdasarkan Analisis Diagram Kartesius

\begin{tabular}{|c|c|}
\hline Kuadran I & Kuadran II \\
\hline $\begin{array}{l}\text { A2: Lapangan penumpukan kontainer memadai dan layak } \\
\text { A5: Tercukupinya jumlah petugas (administrasi, } \\
\text { operasional tally, dan TKBM) } \\
\text { B17: Kemudahan dalam sistem pembayaran } \\
\text { C19: Petugas administrasi memberikan informasi jelas dan } \\
\text { mudah dimengerti } \\
\text { D29: Petugas administrasi memiliki kompetensi }\end{array}$ & $\begin{array}{l}\text { A1: Kelayakan kondisi dermaga kapal } \\
\text { B11: Kesesuaian jadwal bongkar muat kapal } \\
\text { B12: Pelayanan petugas operasional tally dermaga dan } \\
\text { lapangan cepat dan tepat } \\
\text { B14: Petugas TKBM memadai dan terampil dalam } \\
\text { memberikan pelayanan } \\
\text { B16: Tarif yang ditentukan sesuai dengan layanan jasa } \\
\text { yang diberikan } \\
\text { B18: Aktivitas bongkar muat tercatat dengan baik dan } \\
\text { benar } \\
\text { D25: Penerapan operasional di lapangan sesuai dengan } \\
\text { Sistem Operasional Prosedur (SOP) } \\
\text { E30: Petugas administrasi terminal melayani dengan } \\
\text { ramah dan sopan }\end{array}$ \\
\hline Kuadran III & Kuadran IV \\
\hline $\begin{array}{l}\text { A9: Fasilitas umum dalam kondisi baik dan memadai } \\
\text { B15: Alat bongkar muat memiliki produktivitas yang tinggi } \\
\text { C21: Petugas operasional tally dermaga dan lapangan } \\
\text { menerima dan menanggapi keluhan pelanggan dengan } \\
\text { cepat } \\
\text { C22: Problem terhadap alat bongkar dapat terselesaikan } \\
\text { dengan cepat dan tepat oleh petugas } \\
\text { D28: Petugas operasional tally dermaga dan lapangan } \\
\text { memiliki kompetensi } \\
\text { E31: Petugas operasional tally dermaga dan lapangan } \\
\text { melayani dengan ramah dan sopan } \\
\text { E32: Petugas bertanggung jawab terhadap kenyamanan } \\
\text { pelanggan }\end{array}$ & $\begin{array}{l}\text { A6: Kondisi alat bongkar muat di terminal (forklift, RS, } \\
\text { RTG, HMC) baik dan terawat } \\
\text { A7: Jumlah alat bongkar muat di terminal (forklift, RS, } \\
\text { RTG, HMC) memadai } \\
\text { B10: Kesesuaian jadwal sandar kapal ke dermaga } \\
\text { B13: Petugas administrasi memberikan pelayanan dengan } \\
\text { cepat dan tepat } \\
\text { C20: Petugas admin mampu memberikan solusi yang baik } \\
\text { dan tepat terhadap permasalahan administrasi } \\
\text { D24: Petugas operasional post security tanggap terhadap } \\
\text { keamanan dan ketertiban } \\
\text { D27: Terdapat sangsi tegas jika ada penyimpangan } \\
\text { terhadap peraturan dan SOP }\end{array}$ \\
\hline
\end{tabular}




\section{Quality Function Deployment (QFD)}

Indikator-indikator yang dipilih untuk dianalisis lebih lanjut adalah indikator yang memerlukan perbaikan segera. Indikator-indikator tersebut dipilih karena indikator ini dianggap penting oleh konsumen namun pelayanannya masih kurang memuaskan. Indikator-indikator ini selanjut- nya dimasukkan dalam analisis QFD menjadi voice of customer (VOC) yang ditujukan untuk meminimalkan kekurangan-kekurangan dan sebagai masukan bagi manajemen untuk melakukan inovasi pelayanan. Hasil analisis Quality Function Deployment (QFD) dapat ditunjukkan pada Gambar 3 berikut.

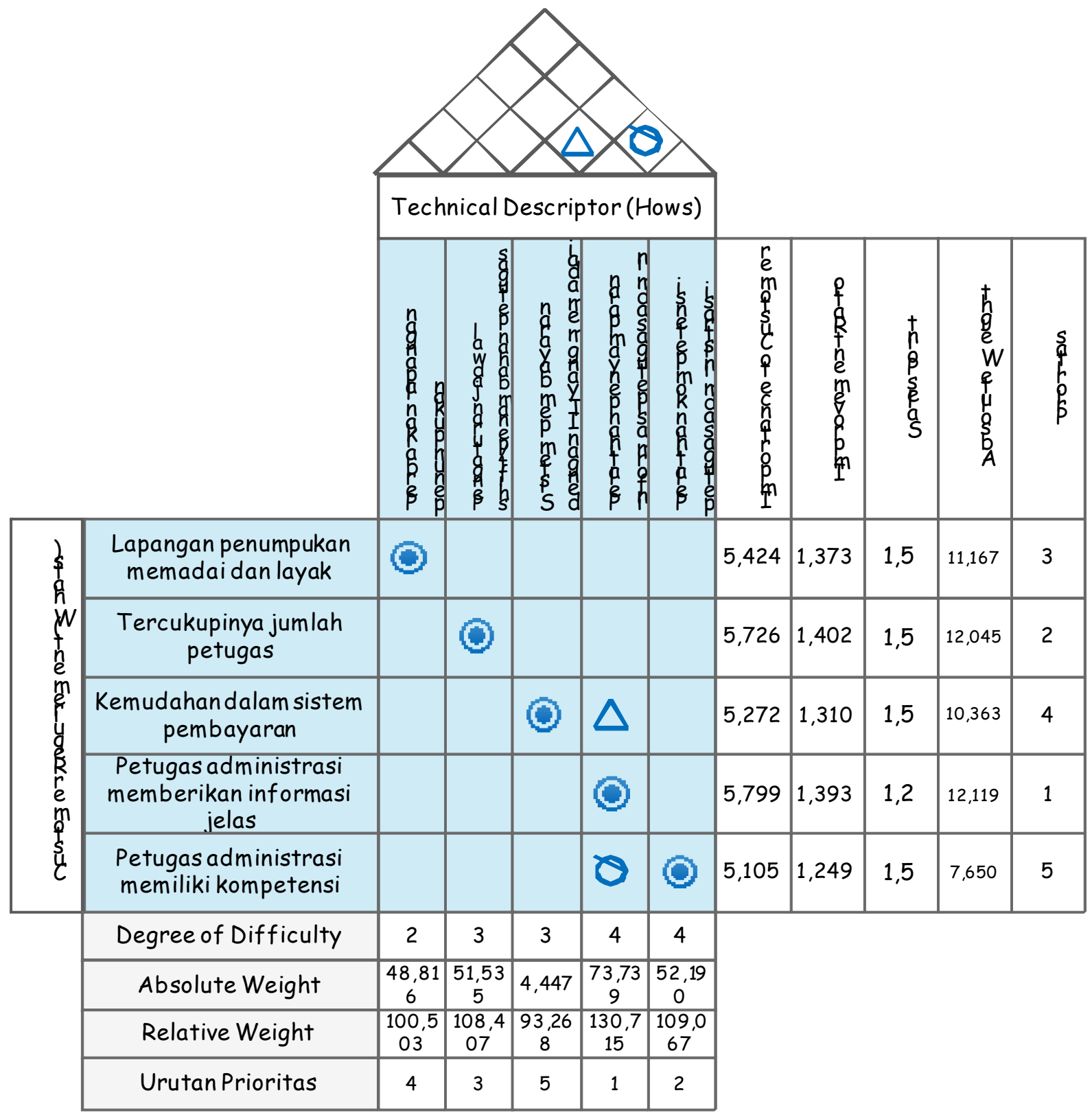

Gambar 3 Hasil Analisis QFD PT TPS 
Berdasarkan hasil QFD tersebut, dapat dilakukan penentuan prioritas perbaikan dan peningkatan indikator kepuasan pelanggan PT TPS baik dari sisi pelanggan maupun teknis. Prioritas untuk masing-masing indikator dapat dilihat pada Tabel 4 berikut.

Tabel 4 Prioritas Perbaikan dan Peningkatan Kepuasan Pelanggan

\begin{tabular}{|c|l|l|}
\hline $\begin{array}{c}\text { Ranking } \\
\text { Prioritas }\end{array}$ & $\begin{array}{l}\text { Indikator berdasarkan } \\
\text { Customer Requirement }\end{array}$ & $\begin{array}{c}\text { Indikator berdasarkan } \\
\text { Technical Descriptor }\end{array}$ \\
\hline 1 & $\begin{array}{l}\text { Petugas administrasi } \\
\text { memiliki kompetensi }\end{array}$ & $\begin{array}{l}\text { Membuat Standar Opera- } \\
\text { sional Prosedur (SOP) untuk } \\
\text { setiap aktivitas di pelabuhan } \\
\text { bagi petugas administrasi }\end{array}$ \\
\hline 2 & $\begin{array}{l}\text { Tercukupinya jumlah } \\
\text { petugas (administrasi, } \\
\text { operasional tally, dan } \\
\text { TKBM) }\end{array}$ & $\begin{array}{l}\text { Memberikan pelatihan kepada } \\
\text { petugas admin setiap bulan } \\
\text { sekali }\end{array}$ \\
\hline 3 & $\begin{array}{l}\text { Lapangan penumpukan } \\
\text { kontainer memadai dan } \\
\text { layak }\end{array}$ & $\begin{array}{l}\text { Melakukan proses rekrutmen } \\
\text { untuk menambah petugas } \\
\text { baru terutama untuk bagian } \\
\text { support dan admin, } \\
\text { operasional tally, dan TKBM }\end{array}$ \\
\hline 4 & $\begin{array}{l}\text { Kemudahan dalam } \\
\text { sistem pembayaran }\end{array}$ & $\begin{array}{l}\text { Melakukan perbaikan, penata- } \\
\text { an ulang, dan penambahan } \\
\text { Lapangan Penumpukan se- } \\
\text { hingga memadai dan layak }\end{array}$ \\
\hline 5 & $\begin{array}{l}\text { Petugas administrasi } \\
\text { memberikan informasi } \\
\text { jelas dan mudah } \\
\text { dimengerti }\end{array}$ & $\begin{array}{l}\text { Menyederhanakan proses } \\
\text { pembayaran dengan menerap- } \\
\text { kan sistem pembayaran satu } \\
\text { pintu dan menggunakan sis- } \\
\text { tem online }\end{array}$ \\
\hline
\end{tabular}

\section{KESIMPULAN DAN SARAN}

Kesimpulan dari hasil penelitian ini adalah sebagai berikut:

1. Hasil analisis Gap menunjukkan seluruh dimensi menghasilkan tingkat kepuasan "cukup puas” (nilai Gap antara -1,5 sampai dengan -0,75) yang dapat diartikan bahwa pada seluruh dimensi kepuasan, pelanggan menilai pelayanan yang diberikan PT TPS sudah cukup memenuhi harapan namun masih belum maksimal.

2. Hasil analisis diagram kartesius terdapat 5 indikator yang memerlukan perbaikan segera antara lain D29: Petugas administrasi memi- liki kompetensi, C19: Petugas administrasi memberikan informasi jelas dan mudah dimengerti, A5: Tercukupinya jumlah petugas (administrasi, operasional tally, dan TKBM), A2: Lapangan penumpukan kontainer memadai dan layak, A9: Fasilitas umum dalam kondisi baik dan memadai, B17: Kemudahan dalam sistem pembayaran.

3. Hasil analisis QFD menunjukkan Indikator yang memerlukan prioritas utama adalah indikator yang berhubungan dengan kompetensi petugas khususnya petugas administrasi. Sehingga rekomendasi pihak manajemen adalah dengan membuat Standar Operasional Prosedur (SOP) untuk setiap aktivitas di pelabuhan bagi petugas administrasi.

Saran untuk penelitian selanjutnya adalah sebagai berikut.

1. Bagi penelitian selanjutnya (akademis) adalah penambahan variabel atau indikator sehingga dapat memberikan informasi yang lebih luas mengenai kepuasan pelanggan di terminal petikemas misalnya dari segi faktor loyalitas pelanggan.

2. Penggunaan beberapa tambahan metode analisis kualitas layanan diperlukan untuk menghasilkan informasi yang lebih akurat dan tepat sehingga dapat dijadikan acuan dalam pengambilan keputusan.

3. Dalam rangka mempermudah proses pengambilan data terhadap pengguna jasa pelabuhan, dapat digunakan dengan menggunakan aplikasi sehingga survei kuesioner dapat berjalan sesuai harapan.

\section{DAFTAR PUSTAKA}

Aritonang, R.L. 2005. Kepuasan Pelanggan. Jakarta: PT Gramedia Pustaka Utama. 
Kotler, P. 1997. Manajemen Pemasaran: Analisis, Perencanaan, dan Implementasi (8th ed.). (A.A. Hermawan, Trans.) Jakarta: Salemba Empat.

Parasuraman, A., Zeithaml, V.A., \& Berry, L.L. 1988. Servqual: A Multiple-Item Scale for Measuring Consumer Perceptions of Service Quality. Journal of Retailing , 64, 12-40.
Randheer, K., \& AL-Motawa, A.A. 2011. Measuring Commuters' Perception on Service Quality Using Servqual in Public Transportation. International Journal of Marketing Studies , 3 (1), 21-34.

Supranto, J. 2001. Pengukuran Tingkat Kepuasan Pelanggan untuk Meningkatkan Pangsa Pasar. Jakarta: PT Rineta Cipta. 
Accounting and Management Journal, Vol. 2, No. 1, July 2018 